\title{
Atypical Thyroid Function Tests and Thyroid Hormone Resistance
}

\author{
Vishwanath Pattan ${ }^{1}$, Ishita Mehra ${ }^{2}$, Syed Anjum Khan ${ }^{3}$, Rahul Kashyap ${ }^{4}$ \\ 1. Endocrinology, Wyoming Medical Center, Casper, USA 2. Internal Medicine, North Alabama Medical Center, \\ Florence, USA 3. Critical Care Medicine, Mayo Clinic Mankato, Mankato, USA 4. Critical Care Medicine, Mayo Clinic, \\ Rochester, USA
}

Corresponding author: Vishwanath Pattan, dr.pattan@gmail.com

\begin{abstract}
Clinical interpretation of thyroid labs is usually straightforward. However, there are rare instances when the atypical profile of thyroid labs warrants systematic investigation to determine the underlying cause. We report the case of a 90-year-old Caucasian male with a chronic history of atrial fibrillation with chronic pacemaker dependence who presented with significantly elevated free thyroxine level $(>7.77 \mathrm{ng} / \mathrm{dL})$ but normal thyroid-stimulating hormone level $(2.15 \mu \mathrm{IU} / \mathrm{mL})$. After ruling out pituitary tumors and artifactual errors due to lab interference, the diagnosis of thyroid hormone resistance was made.
\end{abstract}

Categories: Endocrinology/Diabetes/Metabolism, Internal Medicine

Keywords: thyroid hormone resistance, thyroid hormone receptor beta, atypical thyroid function tests, autosomal dominant, artifactual lab interference

\section{Introduction}

Thyroid labs are one of the most commonly ordered lab tests by primary care physicians. On most occasions, interpretation of thyroid labs is straightforward. However, on rare occasions, primary physicians encounter thyroid lab panels that do not make sense. Normally thyrotropin-releasing hormone (TRH) from the hypothalamus stimulates the production of thyroid-stimulating home (TSH) which, in turn, acts on the thyroid gland to regulate the synthesis and release of tetraiodothyronine (T4) and triiodothyronine (T3). Three carrier proteins, namely, albumin, thyroxine-binding prealbumin, and thyroxine-binding globulin (TBG) bind most of the circulating thyroid hormones in the blood and only a small fraction are available as free hormones (about $0.3 \% \mathrm{~T} 3$ and $0.02 \% \mathrm{~T} 4$ ) [1]. The secreted $\mathrm{T} 4$ and $\mathrm{T} 3$ (especially T3) provide inhibitory feedback to both hypothalamic TRH and pituitary TSH secretion, thus completing the loop. Therefore, the levels of TSH decrease below the normal range when the levels of T4 and T3 are significantly elevated. However, there are rare exceptions to this rule. In this case report, we discuss a very rare and challenging diagnostic dilemma posed by a 90 -year-old Caucasian male who had significantly elevated $\mathrm{T} 4$ levels but had normal TSH levels.

Review began 06/29/2021 Review ended 07/03/2021 Published 07/12/2021

(๑) Copyright 2021

Pattan et al. This is an open access article distributed under the terms of the Creative Commons Attribution License CC-BY 4.0., which permits unrestricted use, distribution, and reproduction in any medium, provided the original author and source are credited.

\section{Case Presentation}

A 90-year-old Caucasian male with a history of atrial fibrillation, hypertension, and primary hypogonadism was referred to endocrinology for evaluation of abnormal thyroid labs and suspected hyperthyroidism.

The patient had a thyroid lab panel ordered routinely which was found to be significantly abnormal. Labs showed TSH of $2.15 \mu \mathrm{IU} / \mathrm{mL}(0.46-4.68 \mu \mathrm{IU} / \mathrm{mL}$ ), free T4 of $>7.77 \mathrm{ng} / \mathrm{dL}$, total T4 of $19.5 \mu \mathrm{g} / \mathrm{dL}$ (reference range: $4.5-12 \mu \mathrm{g} / \mathrm{dL}$ ), and free $\mathrm{T} 3 \mathrm{of} 5 \mathrm{pg} / \mathrm{mL}$ (reference range: $2.0-4.4 \mathrm{pg} / \mathrm{mL}$ ). He was not taking any biotin supplement and did not receive any iodinated contrast before the labs. The patient had a history of atrial fibrillation and had undergone radiofrequency ablation in 1991. He had been on apixaban and testosterone replacement but not on amiodarone, vitamins, or biotin supplements before the lab draw. The patient was asymptomatic. He had been completely dependent on a pacemaker for his heart rate. His heart rate varied from 70-130 beats per minute, and it was programmed for dynamic changes during physical activity and exercise. The patient denied tremors, palpitations, and heat intolerance.

The patient had a history of hypogonadism. He got hot sweats if he missed his testosterone replacement dose. None of his family members had abnormal thyroid blood tests, including his two sons. Physical examination showed a heart rate of 96 beats per minute, blood pressure 136/86 $\mathrm{mmHg}$, respiratory rate 16 breaths per minute, oxygen saturation $97 \%$ on room air, height $180.3 \mathrm{~cm}$, weight $91.5 \mathrm{~kg}$, and body mass index of 28 . The thyroid gland was not palpable. The rest of the physical examination was unremarkable except for bilateral atrophic testicles.

The patient had a mumps infection in the mid-20s during which one of the testicles was inflamed. Subsequently, he had a minor hernia repair, following which the other testicle also atrophied. Thyroidstimulating immunoglobulin and thyrotropin receptor antibody levels were undetectable. The patient could 
not get an MRI because of the pacemaker. CT of the pituitary gland was normal. A summary of pertinent lab workup is provided in Table 1. Workup for anterior pituitary hormone deficiency was negative. Further workup that was recommended included a T4 binding assay (which measures all three binding proteins and the percentage binding of $\mathrm{T} 4$ to each) to see if there was an abnormal binding protein. However, the patient declined further workup.

\begin{tabular}{|c|c|c|c|c|c|c|c|c|}
\hline $\begin{array}{l}\text { Lab values } \\
\text { (reference range) } \\
\text { and time }\end{array}$ & $\begin{array}{l}\text { TSH }(0.46- \\
4.68 \\
\mu \mathrm{lU} / \mathrm{mL})\end{array}$ & $\begin{array}{l}\text { Free T4 } \\
(0.76-1.46 \\
\mathrm{ng} / \mathrm{dL})\end{array}$ & $\begin{array}{l}\text { Free T3 } \\
(2.0-4.4 \\
\mathrm{pg} / \mathrm{mL})\end{array}$ & $\begin{array}{l}\text { Total T4 } \\
(4.5-12 \\
\mu g / d L)\end{array}$ & $\begin{array}{l}\text { Human anti-mouse } \\
\text { antibody }(0-74 \\
\mathrm{ng} / \mathrm{mL})\end{array}$ & $\begin{array}{l}\text { RTH gene } \\
\text { sequencing }\end{array}$ & $\begin{array}{l}\text { Alpha subunit } \\
\text { (reference range: } \\
<2.13 \mathrm{ng} / \mathrm{mL} \text { ) }\end{array}$ & $\begin{array}{l}\text { Prolactin } \\
(4.0-15.2 \\
\mathrm{ng} / \mathrm{mL})\end{array}$ \\
\hline Initial labs in 2019 & 2.15 & $>7.76$ & - & 19.5 & - & - & - & - \\
\hline 4 months later & 2.11 & $>6.5$ & 16.05 & - & - & - & - & - \\
\hline 4.5 months later & 1.8 & $>7.77$ & - & - & $<56$ & - & - & - \\
\hline 5 months later & - & - & - & - & - & - & 0.86 & 9.1 \\
\hline 5.5 months later & 1.82 & $>7.77$ & 5.4 & - & - & - & - & - \\
\hline 11 months later & 2.34 & $>7.77$ & 5.9 & - & - & - & - & - \\
\hline 12 months later & - & - & - & - & - & Negative & - & - \\
\hline
\end{tabular}

\section{TABLE 1: Summary of lab workup.}

RTH: resistance to thyroid hormone; TSH: thyroid-stimulating hormone; T4: tetraiodothyronine; T3: triiodothyronine

\section{Discussion}

Our patient had an elevated free T4 level in the presence of normal TSH, which, in the absence of a pituitary tumor or evidence of artifactual errors in lab assay, is suspicious for thyroid hormone resistance. However, our patient did not have any family history suggestive of thyroid hormone resistance. Many medications can also affect thyroid labs [2-4]. He was not taking any medications, biotin, or had any iodinated contrast that could have affected thyroid labs. Although T4 binding assay was not performed to determine abnormal binding proteins, these are unlikely to affect the free $\mathrm{T} 4$ levels. Thus, in the absence of other causes of atypical thyroid lab profile of elevated free T4 and normal TSH, a diagnosis of thyroid hormone resistance was made. Thyroid hormone resistance is usually an autosomal dominant inherited syndrome. The most common defect in thyroid hormone action is a mutation of the thyroid hormone receptor beta (THR $\beta$ ) gene. Although the majority of $T R \beta$-mediated thyroid hormone resistance is inherited as autosomal dominant, up to $20 \%$ can occur sporadically due to de novo mutations. In addition, negative THR $\beta$ gene sequencing does not exclude THR $\beta$ defects.

The thyroid hormones are responsible for the regulation of various physiological functions by binding to four identified thyroid hormone receptors isoforms, namely, thyroid hormone receptor $\alpha 1$ (THR $\alpha 1$ ), thyroid hormone receptor $\alpha 2$ (THR $\alpha 2$ ), thyroid hormone receptor $\beta 1$ (THR $\beta 1$ ), and thyroid hormone receptor $\beta 2$ (THR $\beta 2$ ). THR $\beta 1$ is expressed in the liver, kidney, and thyroid and THR $\beta 2$ is expressed in the pituitary, hypothalamus, and ear [5]. THR $\beta 2$ has been thought to affect the negative feedback mechanism to the hypothalamus-pituitary-thyroid axis [6]. Resistance to thyroid hormone beta (RTH $\beta$ ) was first described in 1967 [7], and while familial autosomal dominant and autosomal recessive THR $\beta$ mutations have been described in the majority of the cases, up to $20 \%$ of cases can be due to de novo mutations [5,8]. These mutations should be suspected in the context of elevated free T3 and T4, normal or elevated TSH, and normal thyrotropin receptor antibody (TRAb) levels. These derangements in the thyroid function lead to a constellation of clinical abnormalities, including, but not limited to, goiter, tachycardia, short stature, hyperactivity, developmental delay, and hearing impairment, and this is further dependent on the affected thyroid receptor isoform [9-11].

The incidence of RTH has not been clearly defined; however, a study conducted in Oregon reported an incidence of 1 in 40,000 live births and approximately 1,000 cases have been reported in the literature between 1967 and 2006 [11]. Where genetic testing is regarded as the gold standard required for the diagnosis of RTH $\beta$, case reports have brought forward evidence of mosaicism causing varied phenotypical manifestations of RTH $\beta$ within the family without any evident mutations in the THR $\beta$ gene [12]. Approximately $10 \%$ of all RTH is secondary to unknown causes or factors such as the decreased number of receptors and is not attributed to gene mutations [8]. RTH $\beta$ can be further classified into general, peripheral, and pituitary types, where peripheral RTH $\beta$ can have symptoms suggestive of hypothyroidism and pituitary RTH $\beta$ may appear to be causing hyperthyroidism due to inappropriate secretion of TSH [13]. The treatment of RTH $\beta$ is challenging and often symptom-driven. For example, tachycardia can be treated 
with selective beta-blockers; high-dose levothyroxine can be considered for symptomatic hypothyroidism. Thyroid hormone reduction by itself is not recommended because it can increase TSH and lead to goiter. At present, triiodothyroacetic acid is considered to be the most promising treatment as it lowers both thyroid hormone and TSH levels [13]. Our patient was asymptomatic and did not need active management for thyroid hormone resistance.

\section{Conclusions}

In the setting of normal TSH and elevated free T4, after ruling out the pituitary tumor and artifactual lab interference, a high index of clinical suspicion is needed to diagnose thyroid hormone resistance, in the absence of a family history of thyroid hormone resistance and negative THR $\beta$ gene mutation.

\section{Additional Information \\ Disclosures}

Human subjects: Consent was obtained or waived by all participants in this study. Conflicts of interest: In compliance with the ICMJE uniform disclosure form, all authors declare the following: Payment/services info: All authors have declared that no financial support was received from any organization for the submitted work. Financial relationships: All authors have declared that they have no financial relationships at present or within the previous three years with any organizations that might have an interest in the submitted work. Other relationships: All authors have declared that there are no other relationships or activities that could appear to have influenced the submitted work.

\section{References}

1. Sapin R, Schlienger JL: [Thyroxine (T4) and tri-iodothyronine (T3) determinations: techniques and value in the assessment of thyroid function]. Ann Biol Clin (Paris). 2003, 61:411-20.

2. Danzi S, Klein I: Amiodarone-induced thyroid dysfunction. J Intensive Care Med. 2015, 30:179-85. $10.1177 / 0885066613503278$

3. Pattan V, Schaab K, Sundaresh V: Bexarotene: a rare cause of misleading thyroid function tests . Cureus. 2020, 12:e11591. 10.7759/cureus.11591

4. Pattan V, Candula N, Adhikari R, Kashyap R: Phenytoin- medication that warrants deviation from standard approach for thyroid lab interpretation. Cureus. 2020, 12:e11324. 10.7759/cureus.11324

5. Lee JH, Kim EY: Resistance to thyroid hormone due to a novel mutation of thyroid hormone receptor beta gene. Ann Pediatr Endocrinol Metab. 2014, 19:229-31. 10.6065/apem.2014.19.4.229

6. Sørensen HG, van der Deure WM, Hansen PS, et al.: Identification and consequences of polymorphisms in the thyroid hormone receptor alpha and beta genes. Thyroid. 2008, 18:1087-94. 10.1089/thy.2008.0236

7. Refetoff S, DeWind LT, DeGroot LJ: Familial syndrome combining deaf-mutism, stuppled epiphyses, goiter and abnormally high PBI: possible target organ refractoriness to thyroid hormone. J Clin Endocrinol Metab. 1967, 27:279-94. 10.1210/jcem-27-2-279

8. Wang I, Lv H: Identification of a novel mutation in the thyroid hormone receptor $\beta$ gene that causes thyroid hormone resistance syndrome: a case report. Mol Med Rep. 2019, 20:4683-7. 10.3892/mmr.2019.10703

9. Ortiga-Carvalho TM, Sidhaye AR, Wondisford FE: Thyroid hormone receptors and resistance to thyroid hormone disorders. Nat Rev Endocrinol. 2014, 10:582-91. 10.1038/nrendo.2014.143

10. Pappa T, Refetoff S: Human genetics of thyroid hormone receptor beta: resistance to thyroid hormone beta (RTHß). Thyroid Hormone Nuclear Receptor. Methods in Molecular Biology. Plateroti M, Samarut J (ed): Humana Press, New York, NY; 2018. 1801:225-40. 10.1007/978-1-4939-7902-8_18

11. Olateju TO, Vanderpump MP: Thyroid hormone resistance. Ann Clin Biochem. 2006, 43:431-40. 10.1258/000456306778904678

12. Mamanasiri S, Yesil S, Dumitrescu AM, Liao XH, Demir T, Weiss RE, Refetoff S: Mosaicism of a thyroid hormone receptor-beta gene mutation in resistance to thyroid hormone. J Clin Endocrinol Metab. 2006, 91:3471-7. 10.1210/jc.2006-0727

13. Sun H, Cao L, Zheng R, Xie S, Liu C: Update on resistance to thyroid hormone syndrome $\beta$. Ital J Pediatr. 2020, 46:168. 10.1186/s13052-020-00929-x 